\title{
Common Change of Complete Blood Count Parameters in COVID-19: a Literature Review
}

Perubahan Umum Parameter Hitung Darah Lengkap pada COVID-19: Sebuah Tinjauan Pustaka

\author{
Kevin S Dhinata \\ Faculty of Medicine, Airlangga University, Surabaya, Indonesia \\ Jl. Mayjen Prof. Dr. Moestopo 47, Surabaya 60131 \\ Email:kevsastra@gmail.com
}

Received: October 31, 2020

Accepted: July 8, 2021

\begin{abstract}
The rising number of COVID-19 all around the world caused a drastic increase in the occupancy rate of healthcare facilities, triggering overload in some places. This situation requires healthcare workers to evaluate patients' conditions and conduct risk stratification efficiently, especially in a triage situation. Complete blood count is a widely available, economically affordable, and time-efficient testing method which may be significant in assisting those processes. This review article analyzes changes in complete blood count parameters in COVID-19 with the aim to identify the common changes in the parameters in COVID-19 patients and their relation to the disease progression and severity. COVID-19 patients commonly experienced anemia, increased red blood cell distribution width, decreased white blood cell count, significant changes in white blood cell differential count, and thrombocytopenia. It is understood that changes in complete blood count parameters and their extent may provide valuable information about the disease severity and prognosis. In conclusion, COVID-19 patients share a common pattern of complete blood count parameters alterations which is related to the disease progression, severity and prognosis. It is expected that complete blood count examination may play a major role in COVID-19 management, given the valuable information provided by the examination.
\end{abstract}

Keywords: complete blood count; COVID-19; erythrocyte; leukocyte; platelet

\begin{abstract}
Abstrak
Peningkatan jumlah kasus COVID-19 di seluruh dunia menyebabkan tingkat keterisian fasilitas kesehatan oleh pasien meningkat drastis hingga menimbulkan kelebihan beban di beberapa tempat. Keadaan ini memaksa tenaga kesehatan melakukan evaluasi keadaan dan stratifikasi risiko pasien secara efisien, terutama pada situasi triage. Complete blood count (CBC) atau hitung darah lengkap merupakan pemeriksaan yang tersedia luas, terjangkau, dan efisien waktu dan dapat berperan secara signifikan untuk memantau kondisi dan progresivitas penyakit serta memperkirakan keparahan penyakit. Artikel ini merupakan tinjauan pustaka yang menganalisis perubahan parameter hitung darah lengkap pada COVID-19 dengan tujuan untuk mengidentifikasi perubahan parameter hitung darah lengkap pada pasien COVID-19 dan hubungannya dengan progresivitas serta derajat keparahan penyakit. Pasien COVID-19 pada umumnya mengalami anemia, peningkatan distribusi lebar sel darah merah (SDM), penurunan sel darah putih, perubahan signifikan pada hitung jenis sel darah putih, dan trombositopenia. Diketahui bahwa perubahan pada parameter hitung darah lengkap serta derajat perubahannya
\end{abstract}




\section{Review Article}

dapat memberikan informasi berharga mengenai tingkat keparahan penyakit dan prognosis. Sebagai simpulan, pasien COVID-19 menunjukkan pola perubahan parameter hitung darah lengkap yang mirip dan perubahan ini memiliki kaitan dengan progresivitas penyakit, derajat keparahan, dan prognosis. Diharapkan pemeriksaan hitung darah berperan besar dalam manajemen COVID-19.

Kata kunci: hitung darah lengkap; COVID-19; eritrosit; leukosit; trombosit

\section{Introduction}

Infection by the novel SARS-CoV-2 has extended throughout the world and the number of cases keeps on escalating. SARS-CoV-2 is an enveloped, spherical, single-stranded RNA virus that is genetically linked with the previous Severe Acute Respiratory Syndrome coronavirus (SARS-CoV) and the Middle East Respiratory Syndrome coronavirus (MERS-CoV) which caused a large number of respiratory infections worldwide in the previous two decades. The manifestation of the disease caused by the viral infection termed coronavirus disease 2019 (COVID-19), varies from asymptomatic to severe pneumonia and multi-organ failure causing a large number of morbidity and mortality. Fever, dry cough, and fatigue are the most frequent symptoms experienced by the patients. ${ }^{1,2}$

The rapid, continuing increase in the number of COVID-19 patients leads to an increased burden on healthcare facilities and workers. In numerous parts of the world, hospitals and intensive care units experienced a drastic increase in occupancy rate, or even overloaded with patients with moderate to high severity of COVID-19. The ongoing situation may require physicians and healthcare workers to evaluate patients' conditions and estimate the risk and prognosis of the patients promptly so that adequate and essential treatments and procedures can be administered effectively for the wellness of the patients.

The complete blood count is a readily and widely available, economically affordable, and time-efficient testing that has the potential to be used to support the handling of COVID-19. Some studies have shown that complete blood count may provide valuable information to evaluate patients' condition and estimation of prognosis. Complete blood count test results are also readily interpretable by healthcare workers, even by those in the frontlines such as emergency/field hospitals and emergency wards. The rise of many cases, accompanied by overloaded healthcare facilities require healthcare workers to rapidly assess patients' condition and perform risk stratification to treat them accordingly and effectively, especially when in a triage situation. 


\section{Review Article}

This review article analyzes changes in complete blood count parameters (erythrocyte; leukocyte; platelet) in COVID-19 with the aim to identify the common changes in the parameters in COVID-19 patients and their relation to the disease progression and severity.

\section{Complete Blood Count at a Glance}

The complete blood count is widely available, relatively affordable, time-efficient, and readily interpretable laboratory examination which can give accurate information about patients' hematologic parameters. Routine complete blood count with automated hematology analyzers can give information about the estimated number of red blood cells, white blood cells, and platelets in the circulation, including their parameters and differential count. ${ }^{3}$ Technological advances in the last few decades have allowed more sophisticated techniques to be used in automated hematology analyzers. Commonly, a blood sample is aspirated by the machine and then split into several streams and then mixed with various buffers used in the analysis. The examples are differential lysis using detergent with varying strength to separate certain leukocyte types, fluorescent dyes, and reagents to measure hemoglobin and leukocytes containing myeloperoxidase. The common principles used in automated hematology analyzers are but not limited to: First, light scatters at various angles to obtain information about cell size, nuclear lobulation, and cytoplasmic granularity. Second, electrical impedance and conductivity for example to measure blood cell size. Third, fluorescence or light absorbance of stained cells such as in measurement nucleic acid content in cells and analysis of reticulated blood cells. ${ }^{4}$

A complete blood count is routinely used in several conditions such as screening for disease and abnormalities and identifying complications or conditions that need special attention before a medical procedure. They may also be used to support diagnosis and to monitor patients' condition and development by serial examinations. ${ }^{3}$

\section{Erythrocyte Parameters in COVID-19 Patients}

Analysis of erythrocyte parameters in COVID-19 patients shows that a significant proportion of COVID-19 patients developed anemia. Huang et al. (2020) show that 38,2\% of COVID-19 patients had their hemoglobin level decreased. ${ }^{5}$ This finding is in line with a metaanalysis by Taneri et al. which found that the mean hemoglobin level of COVID-19 patients fulfills the anemia diagnosis in men as defined by WHO $(<130 \mathrm{~g} / \mathrm{L})$. Hemoglobin level decreased with age, comorbidities, and severity of the disease. ${ }^{6}$ The degree of the decline in hemoglobin level is correlated with COVID-19 disease severity. Several studies found that the hemoglobin 


\section{Review Article}

level in severe COVID-19 patients and those admitted to ICU were significantly lower than those with a mild and moderate disease without the requirement of ICU admission. Non-surviving patients also tend to have a significantly lower hemoglobin level than those who survived, enabling the measurement and monitoring of hemoglobin levels to be a predictor or warning system for disease severity. ${ }^{6-8}$ Henry et al. (2020) in their study also found that some COVID-19 also had their hematocrit level decreased and increased red blood cell distribution width (RDW). Hematocrit and hemoglobin levels tend to decrease in progressive disease severity while RDW progressively increasing in the opposite direction. The study analysis also found that increased RDW is associated with 9-fold increased odds of severe COVID-19 and 16-fold increased odds of severe acute kidney injury, enabling the measurement of RDW also to be a predictor of disease severity and renal injury complications. ${ }^{9}$

The cause of anemia in COVID-19 is still unclear. Anemia in several chronic diseases may originate from cytokine-mediated suppression of bone marrow erythropoiesis activity and shortened erythrocyte lifespan. ${ }^{10}$ The anemia-causing mechanism in COVID-19 may not be identical and several theories have been proposed. First, the hypoxia caused by the activity of the SARS-CoV-2 virus in the lung tissue and its structures involved in gas exchange may induce inflammation in the body and thus may affect iron metabolism. Apart from being in an inflammatory state, iron metabolism may also be affected due to the action of the innate immune system to inhibit viral replication. Enhanced metabolism and a sufficient amount of iron are required by the virus to replicate inside a human body. The innate immune system will act by activating signaling pathways which lead to the increase of hepcidin hormone produced by the liver which will inhibit the activity of the transporter ferroportin which transports iron out of the cells and lead to decreased amount of iron absorbed from diet in the digestive system. Prolonged infection may lead to decreased iron available for erythropoiesis, causing hemoglobin levels to decrease. ${ }^{6}$ Infection by SARS-CoV-2 may also inflict direct damage towards the bone marrow, causing further disruptions to the erythropoiesis process. ${ }^{9}$

Increased RDW indicates the occurrence of anisocytosis, a condition where a noticeable variation in the size and volume of the red blood cells is present. Higher RDW is typically associated with poorer outcomes in many clinical conditions such as cardiovascular diseases, sepsis, pneumonia, and kidney diseases. ${ }^{4}$ A handful of hypothesis has been discussed about the cause of anisocytosis in COVID-19, especially those with severe disease. COVID-19 infection may inflict damage towards bone marrow, causing impairments in the process of erythropoiesis. This may lead to compensatory hyperplasia of the erythroid cell line and causing a release of 


\section{Review Article}

immature erythrocytes into the circulation. Inflammation may also cause abnormalities of lipid metabolism and fragmentation of structural protein components which will ultimately lead to the breakdown of structural membrane homeostasis and structural integrity of the circulating red blood cells. ${ }^{9,11}$

Widely known coagulation disorder and formation of microthrombi in blood vessels caused by COVID-19 infection further add the disruption to the structural integrity of the red blood cells, causing variation in size leading to anisocytosis and increased RDW. Microthrombi formation is thought to be the trigger of acute kidney injury experienced by some COVID-19 patients. Acute kidney injury could lead to disruption in erythropoietin production, causing further impairments in the erythropoiesis process and therefore leading to more severe anemia and anisocytosis. ${ }^{9}$

\section{Leukocyte Parameters and Differential Count in COVID-19}

Leukocytes or white blood cells have a well-known role in immunity and host response to infection. Plenty of studies have emphasized evaluation of white blood cells and the differential count plays a major role in supporting the COVID-19 diagnosis and predicting the severity of the disease. Researches by Peng et al. (2020) and Sun et al. (2020) found that patients with COVID19 tend to have lower leukocyte levels than healthy people. However, during observation patients with severe disease have higher leukocyte levels than those with mild-moderate disease (7.44 vs $\left.4.40 \times 10^{9} / \mathrm{L} ; \mathrm{P}<0.001\right) .{ }^{12,13}$

Leukocyte differential count may provide more details and may serve as a predictor for the degree of disease severity and prognosis of the patient. Patients with COVID-19 tend to have lower eosinophil and lymphocyte levels and higher levels of neutrophil and monocyte compared to healthy people. ${ }^{12,13}$ Tanni et al. (2020) in New York observed that plenty of COVID-19 patients came out with low or absent eosinophil count and their research showed that $34 \%$ of the patients demonstrated a low absolute eosinophil count with $60 \%$ of them had an absence of eosinophils. During the follow-up, the group of patients with absent eosinophil yield a higher fatality rate than the ones with eosinopenia, and therefore eosinophil count may assist in assessing the probability of the patient having more severe disease. Sun et al. (2020) also found that a lot of COVID-19 patients experienced eosinopenia, and the dynamics of eosinophil level may help to predict and assess the disease severity. Patients who had the eosinophil level bounce back upwards early tend to have a lesser severity compared to those who experienced a delay in the increase of eosinophil. ${ }^{13}$ The pathophysiology of the fall of eosinophil level in COVID-19 patients is still 


\section{Review Article}

unclear, but several probabilities had been discussed. It may be caused by the blockade of eosinophil synthesis and egression from the bone marrow, reduced expression of chemokine receptors and adhesion factors, possible increase in eosinophil apoptosis caused by the inflammation process, and induction of apoptosis by certain cytokine during the infection. ${ }^{14}$

The differential count component that came under the spotlight is increased neutrophils and lymphopenia, causing the elevation of neutrophil-to-lymphocyte ratio (NLR) and monocyteto-lymphocyte ratio (MLR). Researchers understood that those changes are correlated to the disease severity and outcome and are statistically significant. Patients with more severe lymphopenia and higher NLR and MLR tend to develop more severe disease and acute respiratory distress syndrome (ARDS). ${ }^{11-13}$ Liu et al. (2020) found out that the number of in-hospital death was significantly higher in patients with higher NLR and there is an $8 \%$ higher risk of in-hospital mortality for each unit increase in NLR, making it an independent risk factor for in-hospital mortality for COVID-19 patients. ${ }^{2}$ These findings are supported by a meta-analysis conducted by Chan \& Rout (2020) and Zeng et al. (2020) where patients with higher NLR are more likely to develop more disease severity and have a higher mortality rate than those with lower NLR. ${ }^{15,16}$

Increased neutrophils and monocyte are commonly found in bacterial and viral infections. Neutrophil plays an important role in protection against infections and its proliferation is a common physiological response in infections. ${ }^{12,16}$ Patients with severe infections also have a much-weakened immune response and capability to fight infections, making them more prone to bacterial co-infection, enabling a further increase in neutrophil level together with other markers of inflammation and infection such as C-reactive protein and procalcitonin. ${ }^{2}$ An increase in MLR is also found in patients infected with MERS-CoV, which may be related to some extent to the virus causing COVID-19. In MERS, the infection triggered the increase of some cytokines (IL-6 $\&$ IFN- $\alpha$ ) and chemokines (IL-8, CXCL-10, and CCL-5) leading to increasing monocyte level in some patients, but patients of higher severity tend to have a lower percentage of monocyte. ${ }^{12,17}$

Lymphopenia is a common finding in COVID-19. Huang et al. (2020) in their research in China found out that around fifty percent of COVID-19 patients developed lymphopenia. ${ }^{5}$ The decrease in lymphocyte count provided a significant contribution to the increase in NLR and MLR. The underlying cause of lymphopenia is not clearly understood yet, but several theories have been brought up. This may be related to the virus's ability to infect $\mathrm{T}$ lymphocytes through the Angiotensin-converting enzyme 2 (ACE2) receptor and CD147-spike proteins. It is thought that SARS-CoV-2 may directly invade and damaging the lymphocytes. As the infection progress, the virus may proliferate and continue to infect even more lymphocytes. ${ }^{11,15}$ The infection also 


\section{Review Article}

caused a prolonged inflammatory state and continuous $\mathrm{T}$ lymphocyte stimulation. This will eventually lead to a phenomenon called $\mathrm{T}$ cell exhaustion. Exhausted $\mathrm{T}$ cells will be unable to function well and therefore will limit their ability to moderate and control the infection and inflammation. Uncontrolled inflammation may lead to a cytokine storm which will worsen the disease. Cytokine storm will eventually lead to antiproliferation and induction of apoptosis of lymphocytes, causing lymphopenia. ${ }^{18}$ Damage towards lymphatic organs, induced by COVID-19 causing spleen atrophy and lymph node necrosis in some patients may also cause lymphopenia. Patients with severe COVID-19 may also experience increased blood lactic acid level, inhibiting lymphocyte proliferation. ${ }^{17}$

Leukocyte measurement and differential count are widely available, relatively affordable, and time-efficient. On top of that, it may provide plenty of benefits to support the diagnosis and to predict and evaluate the disease severity so that it may be beneficial to start utilizing leukocyte evaluation in managing COVID-19.

\section{Platelet Parameters in COVID-19}

Measurement and evaluation of platelet parameters may possess a role in the management of COVID-19. Thrombocytopenia can be found in several viral infections and is common in critical illnesses. It may suggest the presence of serious organ dysfunction and the intravascular coagulopathy process. ${ }^{19}$ Guclu et al. (2020) found that 25.1\% of COVID-19 patients present with thrombocytopenia at hospital admission. ${ }^{20}$ Several studies also found that thrombocytopenia is associated with disease severity and patient survival in COVID-19. A meta-analysis by Lippi et al. (2020) shows that patients with severe COVID-19 tend to have lower platelet count than those with a milder form of the disease. ${ }^{19}$ Several types of research found out that platelet count in nonsurviving patients is significantly lower than those who survived. ${ }^{20-22}$ Guclu et al. (2020) found that surviving patients expressed a significantly higher platelet count (mean of 207.69 K/uL) compared to the non-survivors $(180.59 \mathrm{~K} / \mathrm{uL}) .{ }^{20}$ Data from Wuhan shows that patient with thrombocytopenia has a higher mortality rate than those with normal thrombocyte count $(30.9 \%$ vs $8.9 \%$ ) and for every $50 \times 10^{9} / \mathrm{L}$ increase in platelet there is a $40 \%$ reduction in mortality risk. ${ }^{22}$

Thrombocytopenia in COVID-19 is possibly multifactorial. It may be caused by the direct attack of SARS-CoV-2 on the bone marrow. Hematopoietic stem cells in the bone marrow also possess ACE2 surface receptors, enabling the virus to infect the cells and replicate until eventually inducing apoptosis of the cells. ACE2 receptors are also found on bone marrow stromal cells and liver cells that synthesize thrombopoietin (TPO), the component responsible for stimulating 


\section{Review Article}

thrombopoiesis, megakaryocyte maturation, and differentiation. This process may inhibit thrombopoiesis, causing thrombocytopenia. Viral infection may also stimulate the synthesis and release of antibodies and immune complexes which may attach to platelets, promoting platelet destruction. Sustained inflammation and cytokine storm may worsen this platelet destruction as some cytokines also work by inhibiting thrombopoiesis. As widely known, COVID-19 infection may damage the lung tissue and pulmonary endothelial cells, causing apoptosis of endothelial cells and vascular leakage. Damage towards those tissues will activate the platelets and triggered the aggregation and encapsulation of platelets, causing coagulation and platelet depletion in the lung microvascular. Megakaryocytes maturation, fragmentation, and platelet production may take place in the capillary beds in the lungs. Damage to lung tissue may decrease the availability of effectively functional capillary beds and contribute to the degradation of platelet production, adding more to the thrombocytopenia. ${ }^{23,24}$ Decreased platelet count, conjoined with lymphopenia in COVID-19 patients led to a higher number of platelet-to-lymphocyte ratio (PLR). Peng et al. (2020) show in their research that compared to a healthy subject, COVID-19 patients have a higher PLR. Higher PLR was also found in a group of patients who developed ARDS, compared to those who didn't, and are statistically significant. ${ }^{12}$

Platelet indices that are widely discussed recently are the mean platelet volume (MPV) and platelet distribution width (PDW). Increased MPV and PDW indicate platelet activation. This may be caused by the damage towards body organs and prolonged inflammation causing increased cytokine and chemokine secretion. Platelets of higher volume also contain more dense granule, produce more thromboxane A2, platelet thrombofactor A, and beta-thromboglobulin. These features enable larger platelet to be more reactive and have more prothrombotic potential. Increased PDW is commonly found in coagulation disorders with hypercoagulation, such as cardiovascular disease. ${ }^{25}$ This may explain why the data obtained from researches in China and Turkey shows that COVID-19 patients tend to have higher MPV and PDW. Furthermore, patients with higher disease severity and mortality had a greater level of MPV and PDW and therefore these parameters may be used to evaluate patients' condition and predict disease severity and mortality. ${ }^{11,20,22}$

A complete blood count measurement is practical, affordable, time-efficient, readily interpretable, and widely available even in peripheral areas. Complete blood count analysis may provide valuable information to monitoring patients' condition, prognosis, and/or risk stratification, and predicting disease severity in COVID-19. A typical finding of CBC analysis in COVID-19 patients are: 


\section{Review Article}

- Erythrocyte parameters: Lower hemoglobin, hematocrit, and increased RDW.

- White blood cell parameters and differential count: Lower leukocyte level, but relatively higher in patients with severe disease, increased neutrophil, lymphopenia (and thus causing elevated NLR and MLR), and eosinopenia up to the absence of eosinophils.

- Platelet parameters: Possible thrombocytopenia, increased PLR, and increased MPV and PDW.

More researches involving a larger number of samples and/or patients with more diverse demographical characteristics are warranted to evaluate the reliability and validity of the usage of complete blood count evaluation in evaluating and monitoring patients' condition, risk stratification, and predicting disease severity and mortality in COVID-19. To the best of the author's knowledge, even though currently complete blood count has been frequently examined in COVID-19 patients, the values of its parameters have not been used routinely in disease severity classification and prognosis determination.

\section{Conclusion}

COVID-19 patients share a common pattern of complete blood count parameters alterations which is related to the disease progression, severity and prognosis. It is with great hope that this time-efficient, affordable, widely available, and readily interpretable method can be used to support the management and handling of this COVID-19 pandemic.

\section{References}

1. Kannan S, Ali Pakeer PSS, Ali AS, Hemalatha K. COVID-19 (Novel Coronavirus 2019) - Recent Trends. Eur Rev Med Pharmacol Sci. 2020;24(4):2006-2011.

2. Liu Y, Du X, Chen J, Jin Y, Peng L, Wang HHX, et al. Neutrophil-To-Lymphocyte Ratio As An Independent Risk Factor For Mortality In Hospitalized Patients With COVID-19. J Infect. 2020;81(1):e6-12.

3. George-Gay B, Parker K. Understanding The Complete Blood Count With Differential. J Perianesthesia Nurs. 2003;18(2):96-117.

4. Kaushansky K, Lichtman MA, Prchal JT, Levi MM, Press OW, Burns LJ, et al. Williams Hematology. 9th Ed. New York: McGraw-Hill; 2015.

5. Huang Y, Tu M, Wang S, Chen S, Zhou W, Chen D, et al. Clinical Characteristics Of Laboratory Confirmed Positive Cases Of SARS-CoV-2 Infection In Wuhan, China: A Retrospective Single Center Analysis. Travel Med Infect Dis. 2020;36(February):1-3.

6. Taneri PE, Gómez-Ochoa SA, Llanaj E, Raguindin PF, Rojas LZ, Roa-Díaz ZM, et al. Anemia And Iron Metabolism In COVID-19: A Systematic Review And Meta-Analysis. Eur J Epidemiol [Internet]. 2020;35(8):763-73. Available from: https://doi.org/10.1007/s10654-020-00678-5

7. Giacomelli A, Ridolfo AL, Milazzo L, Oreni L, Bernacchia D, Siano M, et al. 30-Day Mortality In Patients Hospitalized With COVID-19 During The First Wave Of The Italian Epidemic: A Prospective Cohort Study. Pharmacol Res. 2020;158(May).

8. Fan BE, Chong VCL, Chan SSW, Lim GH, Lim KGE, Tan GB, et al. Hematologic Parameters In Patients With COVID-19 Infection. Am J Hematol. 2020;95(6):E131-4.

9. Henry BM, Benoit JL, Benoit S, Pulvino C, Berger BA, de Olivera MHS, et al. Red Blood Cell Distribution Width (RDW) Predicts COVID-19 Severity: A Prospective, Observational Study From the Cincinnati SARS- 


\section{Review Article}

CoV-2 Emergency Department Cohort. Diagnostics. 2020;10(9):1-9.

10. Leach M. Interpretation Of The Full Blood Count In Systemic Disease - A Guide For The Physician. J R Coll Physicians Edinb. 2014;44(1):36-41.

11. Wang C, Deng R, Gou L, Fu Z, Zhang X, Shao F, et al. Preliminary Study To Identify Severe From Moderate Cases Of COVID-19 Using Combined Hematology Parameters. Ann Transl Med. 2020;8(9):593-593.

12. Peng J, Qi D, Yuan G, Deng X, Mei Y, Feng L, et al. Diagnostic Value Of Peripheral Hematologic Markers For Coronavirus Disease 2019 (COVID-19): A Multicenter, Cross-Sectional Study. J Clin Lab Anal. 2020;(June):1-10.

13. Sun S, Cai X, Wang H, He G, Lin Y, Lu B, et al. Abnormalities Of Peripheral Blood System In Patients With COVID-19 In Wenzhou, China. Clin Chim Acta [Internet]. 2020;507(April):174-80. Available from: https://doi.org/10.1016/j.cca.2020.04.024

14. Tanni F, Akker E, Zaman MM, Figueroa N, Tharian B, Hupart KH. Eosinopenia And Covid-19. J Am Osteopath Assoc. 2020;120(8):504-8.

15. Chan AS, Rout A. Use of Neutrophil-To-Lymphocyte And Platelet-To- Lymphocyte Ratios in COVID-19. J Clin Med Res. 2020;12(7):448-53.

16. Zeng F, Li L, Zeng J, Deng Y, Huang H, Chen B, et al. Can We Predict The Severity Of Coronavirus Disease 2019 With A Routine Blood Test? Polish Arch Intern Med. 2020;130(5):400-6.

17. Yang L, Liu S, Liu J, Zhang Z, Wan X, Huang B, et al. COVID-19: Immunopathogenesis And Immunotherapeutics. Signal Transduct Target Ther [Internet]. 2020;5(1):1-8. Available from: http://dx.doi.org/10.1038/s41392-020-00243-2

18. Fathi N, Rezaei N. Lymphopenia in COVID-19: Therapeutic Opportunities. Cell Biol Int. 2020;44(9):17927.

19. Lippi G, Plebani M, Henry BM. Thrombocytopenia Is Associated With Severe Coronavirus Disease 2019 (COVID-19) Infections: A Meta-Analysis. Clin Chim Acta. 2020;506:145-8.

20. Güçlü E, Kocayiğit H, Okan HD, Erkorkmaz U, Yürümez Y, Yaylacı S, et al. Effect Of COVID-19 On Platelet Count And Its Indices. Rev Assoc Med Bras. 2020;66(8):1122-7.

21. Zhao X, Wang K, Zuo P, Liu Y, Zhang M, Xie S, et al. Early Decrease In Blood Platelet Count Is Associated With Poor Prognosis In COVID-19 Patients-Indications For Predictive, Preventive, And Personalized Medical Approach. EPMA J. 2020;11(2):139-45.

22. Liu Y, Sun W, Guo Y, Chen L, Zhang L, Zhao S, et al. Association Between Platelet Parameters And Mortality In Coronavirus Disease 2019: Retrospective Cohort Study. Platelets. 2020;31(4):490-6.

23. Xu P, Zhou Q, Xu J. Mechanism Of Thrombocytopenia In COVID-19 Patients. Ann Hematol. 2020;99(6):1205-8.

24. Zhang Y, Zeng X, Jiao Y, Li Z, Liu Q, Ye J, et al. Mechanisms Involved In The Development Of Thrombocytopenia In Patients With COVID-19. Thromb Res. 2020;193:110-5.

25. Salamanna F, Maglio M, Landini MP, Fini M. Platelet Functions And Activities As Potential Hematologic Parameters Related To Coronavirus Disease 2019 (Covid-19). Platelets. 2020;31(5):627-32. 